Kazimierz Czerwiński*

ORCID: 0000-0002-0486-4370

Bydgoszcz

\title{
Aktywność obywatelska w organizacjach trzeciego sektora a pedagogia agatologiczna Józefa Tischnera
}

Myśl Józefa Tischnera jest - jak wiadomo - wielowątkowa i jednocześnie mało usystematyzowana. Dopiero różni komentatorzy próbują wyprowadzić z niej konkluzje nieco bardziej uporządkowane. Jednym z autorów, który podjął się takiego zadania, jest Paweł Walczak ${ }^{1}$, który próbuje wysnuć z filozofii tego myśliciela inspiracje o charakterze pedagogicznym. Z różnych Tischnerowskich kategorii, jak między innymi „,dobro”, „,wolność” czy „spotkanie”, wyprowadza możliwość tak zwanej pedagogii agatologicznej. Wśród czterech jej podstawowych założeń - według odczytania Walczaka znajduje się podkreślanie roli wychowawcy w procesie wychowania. Jeśli tak, to próba uzasadnienia, że ta pedagogia może się realizować w trzecim sektorze, będącym organizacyjnym aspektem społeczeństwa obywatelskiego, napotyka na zasadniczą trudność, ponieważ w organizacjach, stowarzyszeniach, fundacjach, ruchach społecznych konstytuujących społeczeństwo obywatelskie zachodzą (przynajmniej potencjalnie) procesy edukacyjne, jed-

* Dr Kazimierz Czerwiński jest adiunktem w Zakładzie Filozofii Wychowania i Edukacji Obywatelskiej w Instytucie Pedagogiki Uniwersytetu Kazimierza Wielkiego w Bydgoszczy. Adres: Uniwersytet Kazimierza Wielkiego, Instytut Pedagogiki, ul. J. K. Chodkiewicza 30, 85-064 Bydgoszcz; e-mail: kazimierz.czerwinski@ukw.edu.pl.

${ }^{1}$ Paweł Walczak, Wychowanie jako spotkanie. Józefa Tischnera filozofia człowieka jako źródło inspiracji pedagogicznych (Kraków: Oficyna Wydawnicza Impuls, 2007). 
nakże o specyficznym charakterze - jest to zasadniczo edukacja nieformalna, w niej zaś nauczyciel - w tradycyjnym pojmowaniu - nie występuje. Pozostają jednakże trzy pozostałe założenia tej pedagogii, a także kontekst - jakże istotny dla różnych myśli Tischnera - jakim jest spotkanie.

Artykuł stanowi próbę uzasadnienia tezy, że mają miejsce dość znaczne paralele między pedagogią agatologiczną a nieformalną edukacją zachodzącą w organizacjach trzeciego sektora - wymagane jest jednak spełnienie pewnych warunków, które zostały wyartykułowane w końcowej części tekstu.

\section{Istota pedagogii agatologicznej}

Paweł Walczak pisze:

Podstawowe terminy Tischnerowskiej antropologii [...]: ja aksjologiczne, osoba, wolność, nadzieja, spotkanie, dobro, stanowią narzędzia opisu procesu wychowania oraz mogą stać się podstawą dla wypracowania systemu zasad i metod wychowania. [...] Model paidei, jaki wyłania się z Tischnerowskiej filozofii, nazwać można pedagogią agatologiczną. Jej rdzeniem jest dynamiczne ujęcie struktury człowieka jako istoty, która się staje. Tischner oddaje ów dynamiczny charakter człowieczeństwa przez metaforę rodzenia: człowiek się dopiero rodzi. Rodzenie oznacza sytuację wydobywania na wierzch czegoś, co jakoś jest, rozświetlenia czegoś, co choć istniało, pozostawało do tej pory niewidoczne. A tym, co istnieje naprawdę, choć niewidoczne, jest, według Tischnera, dobro. Zatem fundamentalnym założeniem pedagogii agatologicznej jest twierdzenie, że człowieczeństwo rodzi się z dobra, stąd budowanie człowieczeństwa w człowieku, to wybieranie tego, co dobre ${ }^{2}$.

Pedagogia agatologiczna może w ogóle zaistnieć, ponieważ osoba - personalistyczna kategoria używana i twórczo rozwijana przez Tischnera - przyjmuje (może przyjmować) postać człowieka agatologicznego, czyli człowieka stającego się, tworzącego samego siebie, odpowiadającego na spotkanie dobra $^{3}$. „Motywem łączącym wszystkie wątki Tischnerowskiej filozofii człowieka jest zaakcentowanie autokreatywnego wymiaru ludzkiej egzystencji, wskazywanie na rolę człowieka w kształtowaniu samego siebie. Ten aspekt

\footnotetext{
2 Tamże, 139.

3 Zob. tamże, 11.
} 
filozofii Tischnera określam - za Barbarą Skargą - koncepcją człowieka agatologicznego"4.

Walczak rekonstruuje cztery podstawowe założenia pedagogii agatologicznej: „ujęcie dobra jako celu wychowania, wolności jako warunku wychowania, podkreślenie roli wychowawcy w procesie wychowania oraz ukazanie struktury relacji międzyosobowych w tym procesie"s.

Ostatnie założenie kieruje myśl w stronę kategorii spotkania. Walczak zauważa: „W pedagogii agatologicznej kluczowym momentem jest spotkanie, przestrzeń międzyosobowa, dialog edukacyjny, który w dobie kryzysu kontaktów międzyludzkich stał się ogromnym problemem w edukacji”’6. A także: ,Spotkanie jest rozumiane jako warunek wejścia człowieka w świat wartości. Wchodząc $w$ relację z drugim człowiekiem, człowiek jednocześnie wchodzi w relację z wartościami, budzi się w nim preferencyjne myślenie oraz doświadczenie odpowiedzialności"?.

Spotkanie - kategoria charakterystyczna dla filozofii dialogu - jest przecież stale obecne (powinno być obecne) w dobrowolnych stowarzyszeniach, a to kieruje te rozważania w stronę społeczeństwa obywatelskiego.

\section{Istota społeczeństwa obywatelskiego}

Społeczeństwo obywatelskie (civil society) definiowane jest jako „przestrzeń na zewnątrz rodziny, władzy państwowej czy obszaru regulowanego mechanizmami rynkowymi, w której ludzie dobrowolnie zrzeszają się, aby działać na rzecz wspólnego dobra"8. Mimo pozornej precyzji tej definicji nie uchyla ona wątpliwości, które bywają artykułowane w debatach toczonych przez filozofów polityki, na przykład czy partie polityczne, jednostki samorządu terytorialnego, związki zawodowe bądź organizacje pracodawców są, czy też nie są instytucjami społeczeństwa obywatelskiego.

Jeden z badaczy społeczeństwa obywatelskiego, Jan Herbst - uchylając się od tych dylematów i unikając ścisłej definicji pojęcia - próbuje je dookreślić następująco:

\footnotetext{
4 Tamże, 15.

5 Tamże, 16.

6 Tamże, 140.

7 Tamże, 121.

${ }^{8}$ Portal Organizacji Pozarzadowych, http://badania.ngo.pl/ [dostęp: 20.09.2017].
} 
Wiadomo, że chodzi o sferę niewymuszonej aktywności ludzi, którą to aktywność można traktować jako narzędzie społecznej zmiany. Wiadomo także, że jest to aktywność związana z określonymi wartościami, takimi jak indywidualna wolność, tolerancja, zaufanie i poczucie przynależności do szerszej zbiorowości. Wiadomo, że odwołuje się do pojęcia wspólnoty, że ma spełniać funkcje kontrolne wobec instytucji państwa, stać na straży dobra wspólnego i przeciwdziałać oligarchizacji systemu demokratycznego?

Cytowany autor akcentuje więc kluczowe wartości oraz funkcje, jakie ten byt może spełniać, nie precyzując, w jakich formach organizacyjnych może się to dokonywać. Inna autorka, Wioletta Szymczak, ujmuje to inaczej, kładąc nacisk właśnie na aspekt organizacyjny: „Społeczeństwo obywatelskie to wyodrębniony od państwa, gospodarki i życia prywatnego obszar, w którym obywatele dobrowolnie i w sposób autonomiczny tworzą stowarzyszenia, fundacje, ruchy, zrzeszenia, zorientowane na wyrażanie, obronę lub też realizację ich potrzeb i aspiracji" ${ }^{10}$. Dalej autorka wymienia jednak również „wartości centralne dla idei społeczeństwa obywatelskiego”. Są to według niej: wolność, pluralizm, autonomia, partycypacja, solidarność i zaufanie ${ }^{11}$.

Wielu autorów unika definiowania społeczeństwa obywatelskiego, wskazując, że jest to pojęcie nieostre i wieloznaczne ${ }^{12}$. Artur Kościański i Wojciech Misztal, wychodząc z takiego założenia, wymieniają wszakże możliwe jego ujęcia. Piszą: „można je widzieć m.in. jako strukturę instytucji politycznych, cywilizowaną i wyzbytą agresji formę redukcji napięć społecznych, system wartości zapewniających trwałość wspólnoty postrzeganej w kategoriach dobra wspólnego lub jako zapośredniczenie potrzeb jednostki i ich zaspokojenie" ${ }^{\prime 13}$. Dalej dodają: „Jest to więc projekt normatywny osadzony na gruncie (z)budowanych instytucji społecznych, np. dialogu obywatelskiego, samorządu, wspólnot lokalnych, zinstytucjonalizowanych organizacji trzeciego

9 Jan Herbst, Oblicza spoleczeństwa obywatelskiego (Warszawa: Fundacja Rozwoju Społeczeństwa Obywatelskiego, 2005), 11.

${ }^{10}$ Wioletta Szymczak, „Znaczenie wartości w tworzeniu społeczeństwa obywatelskiego”, w: Społeczeństwo obywatelskie. Modele teoretyczne i praktyka społeczna, red. Edward Balawajder (Lublin: Wydawnictwo KUL, 2007), 28-29.

11 Tamże, 30-35.

12 Paweł Rudnicki twierdzi nawet, że jest to pojęcie już zupełnie teoretycznie nieprzydatne (z rozmowy w kuluarach pewnej konferencji w Toruniu w grudniu 2012 r.).

13 Artur Kościański, Wojciech Misztal, „Wprowadzenie. Aktywność obywatelska: ile idei, ile praktyki?", w: Społeczeństwo obywatelskie. Między idea a praktyka, red. Artur Kościański, Wojciech Misztal (Warszawa: Wydawnictwo Instytutu Filozofii i Socjologii PAN, 2008), 28. 
sektora (w tym organizacji pożytku publicznego) czy w szerszym rozumieniu instytucji demokracji uczestniczącej”"14. Tak zwany trzeci sektor jest więc tylko częścią tego zjawiska, podczas gdy w potocznym odbiorze zazwyczaj utożsamia się społeczeństwo obywatelskie tylko z trzecim sektorem właśnie bądź nawet zawęża jeszcze bardziej - do organizacji pożytku publicznego. Tymczasem właściwsze byłoby obejmowanie terminem społeczeństwa obywatelskiego wszelkich przejawów uczestniczącej demokracji. Jednakże „trzeci sektor” - termin ten rozpowszechnił się w sferze publicznej - nie jest pojęciem pustym, lecz może być traktowany po prostu jako organizacyjny wymiar społeczeństwa obywatelskiego. Jerzy Szacki pisze:

społeczeństwo obywatelskie to przeważnie po prostu tyle, co trzeci sektor, wyróżniony w rezultacie raczej prostego rozumowania, którego punktem wyjścia jest podział na prywatne i publiczne podmioty działania oraz prywatne i publiczne cele działalności. Sektor pierwszy to rynek, gdzie i podmioty, i cele są prywatne; sektor drugi to rząd, gdzie i podmioty, i cele są publiczne; sektor trzeci to właśnie społeczeństwo obywatelskie, gdzie podmioty są prywatne, cele natomiast publiczne; sektor czwarty, wreszcie, to korupcja, gdzie jest dokładnie na odwrót, podmioty działające są bowiem publiczne, a ich cele prywatne ${ }^{15}$.

Maria Dąbrowska-Bąk wskazuje na znaczne bogactwo znaczeniowe zarówno tego terminu, jak i samego tego zjawiska, które się za nim kryje:

$\mathrm{Na}$ termin „społeczeństwo obywatelskie” składa się wielka różnorodność zjawisk, z których każde mogłoby być tematem osobnej rozprawy. Można wymienić zarówno zdolność do samoorganizowania się społeczeństwa, powszechność postaw współuczestnictwa i współodpowiedzialności, rozwinięte instytucje samorządowe, środowiskowe, np. lekarskie, inżynierskie itd., rozwinięte potrzeby współdecydowania, rozumienia i kontroli sytuacji społecznych, a także znajomość idei demokratycznych oraz stanowczą wolę ich obrony ${ }^{16}$.

14 Tamże, 38.

15 Jerzy Szacki, „Wstęp. Powrót idei społeczeństwa obywatelskiego”, w: Ani książę ani kupiec - obywatel. Idea społeczeństwa obywatelskiego w myśli współczesnej, wyb. Jerzy Szacki (Kraków-Warszawa: Wydawnictwo Znak, Fundacja im. Stefana Batorego, 1997), 54.

16 Maria Dąbrowska-Bąk, ,Zapoznany komponent społeczeństwa obywatelskiego (między etosem granicy a etosem ułatwienia)", w: Edukacja i młodzież wobec społeczeństwa obywatelskiego, red. Kazimierz Przyszczypkowski, Aleksander Zandecki (Poznań-Toruń: Wydawnictwo Edytor, 1996), 85. 
W tym zestawieniu w zasadzie został postawiony znak równości między społeczeństwem obywatelskim a uczestniczącą demokracją czy aktywnym obywatelstwem.

Jerzy Szacki dodatkowo podkreśla, że pojęcie społeczeństwa obywatelskiego jest nie tylko bogate znaczeniowo, ale również niejednoznaczne i różnie rozumiane: „niemal powszechna wydaje się w naukach społecznych świadomość, że pojęcie społeczeństwa obywatelskiego nie jest zrozumiałe samo przez się, lecz wymaga stosunkowo długiego komentarza, który za każdym razem musi zaczynać się niemal od abecadła" ${ }^{17}$. Autor, próbując wyjaśnić tę wieloznaczność, odwołuje się do historii tego pojęcia, wskazując, jak - niejednokrotnie diametralnie - zmieniało się jego znaczenie. Społeczeństwo obywatelskie, będąc przez wieki synonimem społeczeństwa państwowego, stopniowo przeobraziło się bowiem w jego przeciwieństwo, stało się nawet swoistym społeczeństwem odpolitycznionym ${ }^{18}$. W angielskojęzycznym określeniu (civil society) nacisk został położony na civility, co po polsku najlepiej oddać za pomocą określenia „ogłada polityczna” ${ }^{\prime 1}$. W Polsce okresu PRL społeczeństwo obywatelskie było po prostu zaprzeczeniem autokratycznego państwa i to wystarczało za „definicję”. „Pytanie o to, czym ma być społeczeństwo obywatelskie, stało się wszakże kluczowe nazajutrz po upadku autokracji [...]. Wiadomo już było, że społeczeństwo obywatelskie to coś bardzo dobrego, chodziło natomiast o dokładniejsze określenie, co to takiego" 20 . Autor pisze dalej, że idea społeczeństwa obywatelskiego, która odrodziła się w Europie Wschodniej, dodatkowo miała zadziwiająco mało wspólnego z kontekstami gospodarczymi, inaczej niż w dojrzałych demokracjach, gdzie przez dziesięciolecia społeczeństwo obywatelskie bywało rozumiane nawet - pod wpływem ideologii liberalnej - po prostu jako ogół podmiotów gospodarczych funkcjonujących na wolnym rynku ${ }^{21}$. Tymczasem: „największą popularność w Europie Wschodniej zyskał «etyczny model społeczeństwa obywatelskiego» (określenie Piotra Ogrodzińskiego), odznaczający się niezwykle mocnym uwydatnianiem wspólnych wartości wyznawanych przez członków tego społeczeństwa w opozycji do wartości, jakie usiłowało im narzucić państwo"22. Przytoczone głosy, zwłaszcza Jana

\footnotetext{
17 Szacki, „Wstęp”, 6.

18 Zob. tamże, 8-11.

19 Zob. tamże, 13.

20 Tamże, 22.

${ }^{21}$ Zob. tamże, 27.

${ }^{22}$ Tamże, 36.
} 
Herbsta i Wioletty Szymczak, całkowicie to potwierdzają - w ujęciach tych autorów również wyeksponowany został aspekt aksjologiczny; społeczeństwo obywatelskie jest tu pojmowane głównie jako (z)organizowanie się wokół jakichś wartości.

Szacki dookreśla charakter społeczeństwa obywatelskiego w naszym kraju, odnosząc się do kontekstu polityki:

Idea społeczeństwa obywatelskiego oznacza dziś, jak sądzę, generalne zakwestionowanie dychotomii: państwowe-prywatne, zachęcając do uczestnictwa w życiu publicznym, które nie ma wszak koniecznie charakteru politycznego. Konstytutywnym elementem tej idei jest wiara w możliwość i konieczność istnienia sfery pośredniej między życiem prywatnym i państwowym, a więc właśnie sfery publicznej, do której jednostki wchodzą jako osoby prywatne, nie po to jednak, by utwierdzić swe odosobnienie, lecz po to, by je przezwyciężyć bez stawania się trybami machiny państwowej ${ }^{23}$.

Polska specyfika społeczeństwa obywatelskiego polega, mówiąc w uproszczeniu, na próbie ,ucieczki od polityki”. Zapewne wyjaśnienia tego zjawiska można poszukiwać między innymi w swoistej ,alergii”, jaką wielu Polaków ma wobec polityki, pojmowanej zresztą dość stereotypowo i często ograniczanej jedynie do rozgrywek między partiami politycznymi. Według danych Portalu Organizacji Pozarządowych obszary działania polskich organizacji i stowarzyszeń to głównie:

- pomoc społeczna;

- działalność charytatywna;

- podtrzymywanie tradycji narodowej, obywatelskiej i kulturowej;

- ochrona i promocja zdrowia;

- działanie na rzecz osób niepełnosprawnych;

- promocja zatrudnienia i aktywizacja zawodowa;

- działalność na rzecz rozwoju społeczności lokalnych;

- $\quad$ krajoznawstwo oraz wypoczynek dzieci i młodzieży;

- upowszechnianie i ochrona wolności i praw człowieka oraz swobód obywatelskich;

- działania wspomagające rozwój demokracji;

- promocja i organizacja wolontariatu ${ }^{24}$.

${ }_{23}$ Tamże, 56.

24 Zob. Portal Organizacji Pozarzadowych. 
A więc rzeczywiście można tu dostrzec swoistą „,ucieczkę od polityki”, chociaż nie w każdym przypadku.

Znakiem rozpoznawczym dobrze funkcjonującego społeczeństwa obywatelskiego - z czym raczej na pewno zgodzi się większość autorów - jest aktywne uczestnictwo jak największej liczby osób w organizacjach, stowarzyszeniach, fundacjach, ruchach społecznych itp. Dobrowolne stowarzyszenia, w których ludzie gromadzą się wokół jakichś celów, na przykład rozwiązania jakichś problemów, wydają się odpowiednim miejscem szeroko pojętej nieformalnej edukacji. Warto wskazać niektóre argumenty.

\section{Nieformalne uczenie się dorosłych}

Mieczysław Malewski w wielu swoich tekstach mocno podkreśla, że w ciągu minionych kilkudziesięciu lat miała miejsce znacząca ewolucja istoty edukacji, zwłaszcza edukacji dorosłych. Ewolucja ta polegała głównie na rosnącym znaczeniu uczenia się kosztem nauczania, a także na istotnym wzroście znaczenia edukacji nieformalnej, kosztem formalnej i pozaformalnej ${ }^{25}$. Powołując się na Malewskiego, podobnie ujmuje sprawę Ewa Solarczyk-Ambrozik: „Podstawową cechą zmian obserwowanych w edukacji dorosłych jest przesunięcie nacisku z kształcenia na uczenie się dorosłych [...]. Mówiąc o uczeniu się dorosłych, analizuje się ten proces w aspekcie jego znaczenia we współczesnym świecie [...] co oznacza przesunięcie uwagi na uczenie się dorosłych poza instytucjami edukacyjnymi”26.

Z punktu widzenia prowadzonych tu rozważań istotne jest więc zwrócenie uwagi na znaczenie uczenia się nieformalnego. Józef Kargul charakteryzuje je następująco:

Nieformalne uczenie się odbywa się nieplanowo, poza instytucjami, a jego potrzeba wynika z czynności życiowych, z analizy problemów, które człowiek dorosły musi rozwiązać, i wyzwan, którym musi stawić czoła, generowanych przez rozmaite sytuacje. Najbardziej charakterystyczną cechą tego uczenia się

${ }_{25}$ Zob. Mieczysław Malewski, Od nauczania do uczenia się. O paradygmatycznej zmianie w andragogice (Wrocław: Wydawnictwo Naukowe Dolnośląskiej Szkoły Wyższej, 2010), 46-48.

${ }^{26}$ Ewa Solarczyk-Ambrozik, „Oświata dorosłych w zmieniającej się rzeczywistości między nowoczesnością a postmodernizmem”, w: Między przeszłością a przyszłościa edukacji dorostych, red. Agnieszka Stopińska-Pająk (Katowice: Wydawnictwo UŚ, 2005), 65. 
jest refleksyjna analiza doświadczeń płynących z różnych obszarów życia - na przykład pracy zawodowej, życia rodzinnego, relacji międzyludzkich ${ }^{27}$.

Taka edukacja jest więc ściśle powiązana z naturalnie pojawiającymi się problemami egzystencjalnymi uczącego się podmiotu, problemami zarówno o genezie rodzinnej i osobistej, jak i zawodowej czy wynikającej z uczestnictwa w społeczeństwie jako obywatel. $Z$ tych właśnie problemów rodzą się potrzeby edukacyjne, na co zwraca uwagę Elżbieta Dubas:

Potrzeby edukacyjne [...] mogą odnosić się do wszystkich wymiarów życiowej aktywności człowieka. Wymieniam tutaj: aktywność codzienną, rodzinną, zawodową, nieformalne kontakty społeczne, aktywność religijną, korzystanie z mass mediów, aktywność prozdrowotną, kontakt z przyrodą, aktywność fizyczno-rekreacyjną, wypoczynek, czytelnictwo, aktywność intelektualną, hobby, aktywność społeczno-obywatelską, korzystanie z instytucji kulturalnych ${ }^{28}$.

A więc właściwie wszystko, czym żyje człowiek, może stanowić impuls edukacyjny, człowiek nieustannie uczy się przy okazji dowolnej działalności. Jak bowiem pisze Malewski: „W okresie ponowoczesnym uczenie się jest rozumiane jako uboczny produkt aktywności ludzi w świecie praktycznego działania"29.

W efekcie, i niejako przy okazji, dobrowolnej działalności w organizacjach trzeciego sektora u zaangażowanych członków tych organizacji mogą się kształtować lub wznosić na wyższy poziom takie cechy, jak między innymi: aktywność, samosterowność, komunikatywność, krytycyzm, tolerancja, ale też określane przez Piotra Sztompkę mianem prospołecznych więzi moralnych - zaufanie, lojalność i solidarność. Czy jednak w każdym przypadku uczenie się jest ukierunkowane na dobro? Czy uczenie się nieformalne, zachodzące w organizacjach trzeciego sektora, zawsze zasługuje na to, by być waloryzowane pozytywnie i przynosić pozytywne efekty? Jakie muszą być ku temu spełnione warunki?

27 Józef Kargul, Obszary pozaformalnej i nieformalnej edukacji dorostych. Przesłanki do budowy teorii edukacji całożyciowej (Wrocław: Wydawnictwo Naukowe Dolnośląskiej Szkoły Wyższej Edukacji TWP, 2005), 41.

${ }^{28}$ Elżbieta Dubas, „Dorosłość w edukacyjnym paradygmacie, czyli dorosłość jako edukacyjny okres życia człowieka", w: Człowiek na edukacyjnej fali. Współczesne konteksty edukacji dorostych, red. Marek Podgórny (Kraków: Oficyna Wydawnicza Impuls, 2005), 28.

${ }^{29}$ Malewski, Od nauczania, 208. 


\section{Trzeci sektor jako miejsce realizacji pedagogii agatologicznej}

Tischner pisze: „Polityka to - w radykalnym znaczeniu tego słowa nauka sensownego projektu dla ludzkich poświęceń na aktualnym etapie dziejów" "30. To bardzo interesujące określenie polityki, jakże różne od tych zawartych w leksykonach filozofii politycznej czy politologii, ale równie dalekie od pojmowania potocznego. Tym, co szczególnie osobliwe, jest obecność kategorii poświęcenia. Ale ta kategoria pojawia się u Tischnera również wtedy, gdy pisze o spotkaniu:

Ten tylko, kto doświadczył spotkania, może mówić, że doświadczył źródłowo jakiegoś konkretnego dobra i zła, jakiejś tragiczności, jakiejś wolności oraz głosu imperatywu kategorycznego, który od drugiego szedł ku niemu. Tylko ten, kto spotkał, może szczerze poświęcić siebie. Poza spotkaniem wszystkie wymienione wyżej pojęcia są pojęciami wypranymi z doświadczenia. Doświadczenie aksjologicznie ciąży ku jakiemuś poświęceniu ${ }^{31}$.

Spotkanie według Tischnera jest przeniknięte tragicznością ludzkiego losu, niejednokrotnie zmusza do przeżywania intensywnych emocji, stwarza okazję do wewnętrznej przemiany: „Spotkać, znaczy coś więcej i coś innego, niż zobaczyć, usłyszeć, podać rękę. Co znaczy spotkać? Spotkać to osiągnąć bezpośrednią naoczność tragiczności przenikającej wszystkie sposoby bycia Drugiego" 32 . „To [spotkanie - K. C.] wtrąca mnie «na drogę» radykalnej przemiany wewnętrznej: metanoi, konwersji, nawrócenia, czy jak ją trzeba nazwać. Nie wiemy dokładnie, dokąd nas ta droga doprowadzi”33. Nie trzeba dodawać, że właśnie uczestnictwo w różnych instytucjach społeczeństwa obywatelskiego niesie możliwość (a właściwie konieczność) spotkań. Przy czym oczywiście nie każde spotkanie - w potocznym rozumieniu - niesie takie możliwości; zapewne należałoby w tym kontekście pisać ten wyraz małą lub wielką literą - w zależności od znaczenia i rangi, jaką posiada.

\footnotetext{
30 Józef Tischner, Myślenie wedtug wartości (Kraków: Wydawnictwo Znak, 2000), 521.

31 Tamże, 514.

32 Tamże, 512.

33 Tamże, 514.
} 
Początkiem spotkania jest dialog, który dla Tischnera jest „wyjściem z kryjówek":

Dialog oznacza, że ludzie wyszli z kryjówek, zbliżyli się do siebie, rozpoczęli wymianę zdań. Początek dialogu - wyjście z kryjówki - jest już dużym wydarzeniem. Trzeba się wychylić, przekroczyć próg, wyciągnąć rękę, znaleźć wspólne miejsce do rozmowy. Miejsce to nie będzie już kryjówką, w której człowiek pozostaje sam ze swoim lękiem, lecz miejscem spotkania, zaczątkiem jakiejś wspólnoty, być może początkiem domu. Ileż przeszkód potrzeba niekiedy pokonać, by rozpocząć dialog! Ile cierpliwości, by go kontynuować! Trzeba nie tylko przezwyciężyć lęk i usunąć uprzedzenia, ale również wynaleźć taki język, który dla obu stron znaczy to samo ${ }^{34}$.

Trudno o lepszą „dramatyczną” charakterystykę tych wszystkich kolejnych etapów działań, które (niektórzy) ludzie podejmują, by zrobić coś wspólnie, by się zorganizować wokół jakiejś wartości bądź dla rozwiązania jakiegoś problemu, by przeciw czemuś wspólnie zaprotestować itp. Społeczeństwo obywatelskie zaczyna się od dialogu, a następnie zachodzi spotkanie (być może nawet - Spotkanie).

Tischner pisze o dwu możliwych przeciwstawnych formach duchowego życia człowieka, z których jedna jest w istocie negacją życia (chodzi głównie o strach, trwogę, doznanie samotności, doznanie winy, rozpaczy itp.), a druga „stanowi prawdziwe «zrodzenie», Genesis z Ducha" 35 . Ta druga forma wymaga, by człowiek ukierunkowywał się na wartości, czy - jak to określa Tischner - odpowiadał na „przyciąganie” wartości pozytywnych. Ale: „(r)olę kluczową w całym «tworzeniu» odgrywa doświadczenie sytuacji granicznych: przyjmowania odpowiedzialności, poświęcenia w miłości, spełniania aktów męstwa w obliczu śmierci itd."36. Dopiero bowiem zmierzenie się z sytuacjami granicznymi gwarantuje najwyższy poziom autentyzmu egzystencji i owego wzrastania ku wartościom. Sytuacje graniczne zaś mają miejsce wyłącznie w kontekstach społecznych.

Jakie muszą być spełnione warunki do tego, by społeczeństwo obywatelskie rzeczywiście mogło stanowić miejsce realizacji założeń pedagogii

34 Józef Tischner, „Etyka solidarności”, w: Józef Tischner, Etyka solidarności oraz Homo sovieticus (Kraków: Wydawnictwo Znak, 2005), 21.

35 Józef Tischner, Świat ludzkiej nadziei (Kraków: Wydawnictwo Znak, 2000), 200.

36 Tamże, 201. 
agatologicznej - w wersji nieformalnej edukacji dorosłych? Nasuwają się w pierwszej kolejności następujące odpowiedzi:

1. Organizacja, stowarzyszenie, ruch społeczny itp., w których działa dany obywatel (lub do których zamierza przystąpić), powinny gromadzić ludzi autentycznie zainteresowanych realizacją misji danej organizacji, nie zaś takich, których motywacje są innego rodzaju. Galia Chimiak stworzyła ciekawą typologię motywacji działań w sferze publicznej. Wyróżniła 10 grup powodów, wśród których dominują oczywiście te o charakterze prospołecznym i altruistycznym, ale są również takie jak: motywacja wynikająca z frustracji (odczuwanie winy, obrona samego siebie przed samym sobą, rozwiązywanie różnych osobistych problemów), motywacja związana z władzą (osiągnięcie lub utrzymanie statusu społecznego, chęć zrobienia kariery, zdobycie prestiżu, reputacji), chęć zapełnienia wolnego czasu (ucieczka przed nudą, poszukiwanie nowych doznań) ${ }^{37}$. Nie o takie motywacje chodzi.

2. Organizacja powinna mieć na celu - tak czy inaczej sprecyzowanedobro wspólne, nie może zaś być nastawiona na realizację prywatnych interesów jej członków. W tym kontekście Andrzej Kasperek zwraca uwagę na niebezpieczeństwo tak zwanego amoralnego familizmu (określenie ukute w 1958 roku przez Edwarda Banfielda). Zjawisko to występuje wówczas, gdy więzi silne (pokrewieństwo, przyjaźń) dominują nad więziami słabymi (objawiającymi się głównie partycypacją w stowarzyszeniach). Amoralny familizm skutkuje zawężeniem horyzontów życia społecznego, ograniczeniem zaufania tylko do członków własnej rodziny, nieufnością do reprezentantów grup obcych i traktowaniem ich instrumentalnie z punktu widzenia interesów własnych i swojej rodziny ${ }^{38}$. Dobro wspólne kategoria dość kłopotliwa teoretycznie oraz niejednokrotnie trudna do zdefiniowania i wyartykułowania w przypadku konkretnego stowarzyszenia - powinna wszakże stanowić o kierunkach działania

37 Zob. Galia Chimiak, „Motywacje społeczników działających w organizacjach pozarządowych w Polsce. Próba typologii”, w: Samoorganizacja społeczeństwa polskiego. III sektor i wspólnoty lokalne w jednoczacej się Europie, red. Piotr Gliński, Barbara Lewenstein, Andrzej Siciński (Warszawa: Wydawnictwo Instytutu Filozofii i Socjologii PAN, 2004), 110-111.

38 Zob. Andrzej Kasperek, „Autonomia i demokracja w perspektywie społeczeństwa postmaterialistycznego", w: Samorządność wczoraj i dziś. Wychowanie do społeczeństwa obywatelskiego, red. Andrzej Murzyn (Kraków: Oficyna Wydawnicza Impuls, 2011), 111. 
dobrze pojmowanej wspólnoty. Wymaga to również, by działania nastawione na realizację dobra wspólnego oddzielić od osobistych sympatii czy powiązań rodzinnych, jakie przecież miewają miejsce w niejednym stowarzyszeniu. Tylko wówczas jest szansa, że uczenie się w takiej organizacji przyniesie efekty waloryzowane pozytywnie.

3. Organizacja powinna zajmować się czymś „poważnym”; zapewne na przykład Stowarzyszenie Hodowców Kanarków, choć samo w sobie nieszkodliwe i być może nawet jakoś pożyteczne (przynajmniej w sensie zapełniania wolnego czasu i realizacji hobby), nie stworzy zbyt wielu możliwości zaistnienia owych Tischnerowskich sytuacji granicznych czy dramatycznego spotkania z drugim człowiekiem. Takie możliwości pojawią się zaś na pewno w stowarzyszeniu prowadzącym hospicjum czy też każdym innym, nastawionym na działalność charytatywną.

4. Uczenie się nieformalne nader często przyjmuje postać uczenia się od siebie nawzajem, zwłaszcza we wspólnocie. Do tego niezbędne jest płynne przechodzenie od roli „ucznia” do roli „nauczyciela" i z powrotem. Niewskazane jest więc, by liderzy stowarzyszeń czy animatorzy ruchów społecznych kreowali się na mądrzejszych od innych i ustawiali się w pozycji tych, którzy są skłonni pouczać pozostałych, ponieważ ,wiedzą lepiej” i sami nie są już gotowi uczyć się czegokolwiek. Takie zagrożenie może zresztą dotyczyć nie tylko liderów, ale również szeregowych działaczy, zwłaszcza tych, którzy mają tendencję do narzucania swego zdania innym.

5. Warto wspomnieć o pewnym warunku nadrzędnym, w zasadzie ustrojowym - musi istnieć rzeczywiście pełna swoboda stowarzyszania się i nieskrępowanej działalności wszelkich ruchów społecznych, organizacji i stowarzyszeń, oczywiście pod warunkiem przestrzegania przez nie prawa; to wszakże mamy w demokratycznej Polsce (raczej) zagwarantowane.

To zapewne nie wszystkie warunki konieczne. Wydaje się jednak, że spełnienie chociażby wymienionych dałoby szansę rzeczywistej realizacji zarówno wspominanej zmiany paradygmatycznej w edukacji dorosłych, jak i realizacji założeń pedagogii agatologicznej; przy okazji - mogłoby się również przyczynić do istotnego zwiększenia poziomu obywatelskiej aktywności Polaków. 


\section{Civic Activity in Third Sector Organizations \\ Versus the Agatological Pedagogy of Józef Tischner \\ (Summary)}

Civic society identified as the third sector consists of institutions, associations, foundations, social movements and others of this type, where people voluntarily associate and work for the common good. Effective acting in these organizations forms features and attitudes of the third sector members such as self-steering, communicativeness, criticism, but also trust, loyalty, solidarity, tolerance, etc. On the occasion of other (alternative) activities, informal learning from each other happens and this kind of adults' lifelong learning - according to Mieczysław Malewski - is a new andragogical paradigm. It corresponds with Józef Tischner's conception of the agatological pedagogy at the core of which lies the recognition of a human as a being who is becoming and who is oriented towards good. This article is a trial of asserting the described dependence as an argument position.

Keywords: civic society; adult education; informal learning; agatological pedagogy; Tischner.

\section{Aktywność obywatelska w organizacjach trzeciego sektora a pedagogia agatologiczna Józefa Tischnera (Streszczenie)}

Społeczeństwo obywatelskie, określane też jako trzeci sektor, składa się z organizacji, stowarzyszeń, fundacji, ruchów społecznych itp., w których ludzie dobrowolnie zrzeszają się i działają dla realizacji dobra wspólnego. Efektywne działanie w tych organizacjach kształtuje u ich członków takie cechy i postawy jak: aktywność, samosterowność, komunikatywność, krytycyzm, ale też zaufanie, lojalność, solidarność, tolerancję itp. Ma tu miejsce uczenie się nieformalne, przy okazji innych działań, od siebie nawzajem - a ten rodzaj całożyciowego uczenia się dorosłych jest zdaniem Mieczysława Malewskiego nowym paradygmatem andragogicznym. Koresponduje to z Józefa Tischnera koncepcją pedagogii agatologicznej, której rdzeniem jest ujęcie człowieka jako istoty, która staje się i która jest ukierunkowana na dobro. Artykuł stanowi próbę uargumentowania tej zależności.

Słowa kluczowe: społeczeństwo obywatelskie; edukacja dorosłych; uczenie się nieformalne; pedagogia agatologiczna; Tischner. 


\section{Bibliografia}

Chimiak, Galia. „Motywacje społeczników działających w organizacjach pozarządowych w Polsce. Próba typologii”. W: Samoorganizacja spoleczeństwa polskiego. III sektor i wspólnoty lokalne w jednoczacej się Europie, red. Piotr Gliński, Barbara Lewenstein, Andrzej Siciński, 106-134. Warszawa: Wydawnictwo Instytutu Filozofii i Socjologii PAN, 2004.

Dąbrowska-Bąk, Maria. „Zapoznany komponent społeczeństwa obywatelskiego (między etosem granicy a etosem ułatwienia)". W: Edukacja i młodzież wobec społeczeństwa obywatelskiego, red. Kazimierz Przyszczypkowski, Aleksander Zandecki, 85-97. Poznań-Toruń: Wydawnictwo Edytor, 1996.

Dubas, Elżbieta. „Dorosłość w edukacyjnym paradygmacie, czyli dorosłość jako edukacyjny okres życia człowieka”. W: Człowiek na edukacyjnej fali. Wspótczesne konteksty edukacji dorostych, red. Marek Podgórny, 25-38. Kraków: Oficyna Wydawnicza Impuls, 2005.

Herbst, Jan. Oblicza spoteczeństwa obywatelskiego. Warszawa: Fundacja Rozwoju Społeczeństwa Obywatelskiego, 2005.

Kargul, Józef. Obszary pozaformalnej i nieformalnej edukacji dorostych. Przesłanki do budowy teorii edukacji całożyciowej. Wrocław: Wydawnictwo Naukowe Dolnośląskiej Szkoły Wyższej Edukacji TWP, 2005.

Kasperek, Andrzej. „Autonomia i demokracja w perspektywie społeczeństwa postmaterialistycznego". W: Samorzadność wczoraj i dziś. Wychowanie do spoteczeństwa obywatelskiego, red. Andrzej Murzyn, 101-116. Kraków: Oficyna Wydawnicza Impuls, 2011.

Kościański, Artur, Wojciech Misztal. „Wprowadzenie. Aktywność obywatelska: ile idei, ile praktyki?”. W: Społeczeństwo obywatelskie. Między idea a praktyka, red. Artur Kościański, Wojciech Misztal, 27-39. Warszawa: Wydawnictwo Instytutu Filozofii i Socjologii PAN, 2008.

Malewski, Mieczysław. Od nauczania do uczenia się. O paradygmatycznej zmianie w andragogice. Wrocław: Wydawnictwo Naukowe Dolnośląskiej Szkoły Wyższej, 2010.

Solarczyk-Ambrozik, Ewa. „Oświata dorosłych w zmieniającej się rzeczywistości między nowoczesnością a postmodernizmem". W: Między przeszłościq a przyszłością edukacji dorostych, red. Agnieszka Stopińska-Pająk, 56-68. Katowice, Wydawnictwo UŚ, 2005.

Szacki, Jerzy. „Wstęp. Powrót idei społeczeństwa obywatelskiego”. W: Ani ksiązę ani kupiec - obywatel. Idea spoleczeństwa obywatelskiego w myśli wspótcze- 
snej, wyb. Jerzy Szacki, 5-62. Kraków-Warszawa: Wydawnictwo Znak, Fundacja im. Stefana Batorego, 1997.

Szymczak, Wioletta. „Znaczenie wartości w tworzeniu społeczeństwa obywatelskiego". W: Społeczeństwo obywatelskie. Modele teoretyczne i praktyka spoleczna, red. Edward Balawajder, 27-45. Lublin: Wydawnictwo KUL, 2007.

Tischner, Józef. Etyka solidarności oraz Homo sovieticus. Kraków: Wydawnictwo Znak, 2005.

Tischner, Józef. Myślenie wedtug wartości. Kraków: Wydawnictwo Znak, 2000.

Tischner, Józef. Świat ludzkiej nadziei. Kraków: Wydawnictwo Znak, 2000.

Walczak, Paweł. Wychowanie jako spotkanie. Józefa Tischnera filozofia człowieka jako źródto inspiracji pedagogicznych. Kraków: Oficyna Wydawnicza Impuls, 2007. 